\title{
Variasi Fenotipe, Korelasi Dan Regresi Morfometri Calon Induk Kelinci Di Desa Nongko Sewu Kecamatan Tumpang Kabupaten Malang
}

\section{Phenotype Variation, Correlation And Regression Of Morphometry Traits In Rabbit Doe Candidate At Nongko Sewu, Tumpang, Malang District}

\author{
Deni Sartika $^{1}$, Mudawamah ${ }^{2 *}$ dan Oktavia Rahayu Puspitarini ${ }^{3}$ \\ ${ }^{1,2,3}$ Fakultas Peternakan, Universitas Islam Malang \\ Jl. MT. Haryono 193 Malang \\ *Corresponding author: mudawamah@unisma.ac.id
}

Sejarah artikel : Menerima : 27 Januari 2020 Revisi : 05 Maret 2020 Diterima : 06 Juni 2020 Online : 30 Juni 2020

\begin{abstract}
ABSTRAK
Penelitian ini bertujuan untuk menentukan variasi fenotipe, korelasi dan regresi fenotipe morfometri pada berbagai bangsa calon induk kelinci di Desa Nongko Sewu Tumpang Malang. Penelitian ini menggunakan ternak kelinci calon induk berumur 9 bulan yang terdiri dari kelinci New Zealand White (NZW) 14 ekor, Flamish Giant (FG) 20 ekor dan kelinci Lokal (L) 20 ekor. Peralatan penelitian terdiri dari alat ukur dalam satuan centimeter, timbangan, keranjang tempat kelinci dan alat recording untuk menulis dan dokumentasi gambar. Penelitian ini menggunakan metode studi kasus. Variabel yang diamati dalam penelitian ini yaitu bobot badan (BB), dan ukuran tubuh (lingkar dada atau LD dan panjang badan atau PB). Data yang diperoleh ditabulasikan dalam bentuk table dan dianalisis dengan korelasi dan regresi sederhana melalui software SPSS version 16.0. Berdasarkan hasil penelitian menunjukkan bahwa variasi fenotipe, korelasi dan regresi morfometri pada berbagai bangsa calon induk kelinci adalah bernilai positif. Rataan dan variasi fenotipe pada morfometri LD dari berbagai induk kelinci adalah 24,36 $\pm 0,82 \mathrm{~cm}$ dan 0,67 (NZW); 22,98 $\pm 0,79 \mathrm{~cm}$ dan 0,62 (FGL); 21,65 $\pm 2,26$ $\mathrm{cm}$ dan 5,11 (L). Rataan dan variasi fenotipe pada morfometri PB dari induk kelinci adalah 27,32 \pm $0,91 \mathrm{~cm}$ dan 0,82 (NZW); $25,00 \pm 0,65 \mathrm{~cm}$ dan 0,42 (FGL); 22,15 $\pm 1,48 \mathrm{~cm}$ dan 2,19 (L). Rataan dan variasi fenotipe pada sifat BB dari berbagai induk kelinci adalah 2,46 $\pm 0,31 \mathrm{~kg}$ dan 0,10 (NZW); 2,40 \pm $0,15 \mathrm{~kg}$ dan 0,02 (FGL); $1,96 \pm 0,16 \mathrm{~kg}$ dan 0,03 (L). Korelasi dan koefisien determinasi hubungan antara BB (Y) dengan PB (X) adalah 0,053 dan -0,231 (NZW); 0,158 dan -0,398 (FGL); 0,198 dan 0,445 (L). Korelasi dan koefisien determinasi hubungan antara BB (Y) dengan LD (X) adalah 0,105 dan 0,324 (NZW); 0,007 dan -0,086 (FGL); 0,038 dan 0,196 (L). Hasil uji regresi menunjukkan bahwa tidak ada hubungan antara $B B$ dengan $P B$ dan $B B$ dengan $L D$ kecuali pada calon induk $L$ yaitu hubungan nyata $(P<0,05)$ antara BB $(X)$ dan $P B(Y)$ dengan persamaan regresi $Y=0,906+0,048 X$. Kesimpulan variasi fenotipe $L D$ dan $P B$ calon induk kelinci $L$ paling tinggi dibandingkan dengan calon induk kelinci NZW dan FGL, sedangkan variasi fenotipe BB paling tinggi pada calon induk NZW. Nilai korelasi dan determinasi hubungan sifat morfometri pada calon induk NZW, FGL dan $L$ kategori sangat rendah sampai rendah keeratannya. Bobot badan calon induk kelinci Lokal bisa diduga dari panjang badan dengan persamaan regresi $\mathrm{BB}=0,906+0,048 \mathrm{~PB}$.
\end{abstract}

Kata Kunci: bobot badan, ukuran tubuh, kelinci

\section{ABSTRACT}

This research aimed to determine the phenotype variation, study and analyze the relationship of morphometric phenotypes in various rabbit breeders at Nongko Sewu, Tumpang, Malang District. Candidate Rabbit breeds were nine months old with three breeds contained 14 heads of New Zealand 
White (NZW) 20 Flamish Giant (FG) and 20 Local (L). The research used a case study method with morphometry measurements included body weight (BW) and body measurement (chest circumference or $\mathrm{CC}$ and body length or $\mathrm{BL}$ ). Data obtained was tabulated and than analyzed with correlation and regression by SPSS software version 16.0. Based on the results of the study showed phenotype variation, correlation and regression of morphometric trait in various rabbit breeds were positive. The average and phenotype variations of CC were $24.36 \pm 0.82 \mathrm{~cm}$ and 0.67 (NZW); $22.98 \pm 0.79 \mathrm{~cm}$ and $0.62(\mathrm{FGL}) ; 21.65 \pm 2.26 \mathrm{~cm}$ and $5.11(\mathrm{~L})$. The average and phenotype variations of $\mathrm{BL}$ were $27.32 \pm$ $0.91 \mathrm{~cm}$ and 0.82 (NZW); $25.00 \pm 0.65 \mathrm{~cm}$ and 0.42 (FGL); $22.15 \pm 1.48 \mathrm{~cm}$ and $2.19(\mathrm{~L})$. The average and phenotype variations of BB were $2.46 \pm 0.31 \mathrm{~kg}$ and 0.10 (NZW); $2.40 \pm 0.15 \mathrm{~kg}$ and 0.02 (FGL); $1.96 \pm 0.16 \mathrm{~kg}$ and $0.03(\mathrm{~L})$. The correlation and determination coefficient of the relationship between BW $(\mathrm{Y})$ and $\mathrm{BL}(\mathrm{X})$ were 0.053 and -0.231 (NZW); 0,158 and $-0,398(\mathrm{FGL}) ; 0,198$ and $0,445(\mathrm{~L})$. The correlation and coefficient of determination of the relationship between $B W(Y)$ and $C C(X)$ were 0.105 and 0.324 (NZW); 0.007 and -0.086 (FGL); 0.038 and $0.196(\mathrm{~L})$. Regression analysis showed no relationship between $B W$ with $B L$ and $B W$ with $C C$ except $L$ breed. The relationship $(P<0.05)$ between $\mathrm{BB}(\mathrm{X})$ and $\mathrm{BL}(\mathrm{Y})$ with a regression equation $\mathrm{Y}=0.906+0.048 \mathrm{X}$. Phenotype variation of $\mathrm{CC}$ and $\mathrm{BL}$ of Local breed was highest compared to NZW and FGL, while the phenotype variation of BB was highest in the NZW. The relationship of morphometric traits of NZW, FGL and L was a low category. Candidate doe of Local Rabbits can predict body weight through body length with a regression equation $\mathrm{BW}=$ $0.906+0.048$ LB.

Kata Kunci: body weight, body measurement, rabbit

\section{PENDAHULUAN}

Hewan mamalia kelinci secara klasifikasi berasal dari family family Leporidae dan ordo Lagomorpha yang banyak tersebar di seluruh dunia. Berdasarkan produktivitasnya, kelinci terbagi dua tipe yaitu: pedaging (meat type) dan hias (fancy type). Ternak ini juga merupakan salah satu komoditas peternakan yang menunjang pendapatan peternak (Fadli et al., 2019) melalui daging yang berkualitas tinggi Menurut Blasco and Gomez (1993), Zotte (2002), Simonova et al. (2010). Menurut Sartika (2005) daging kelinci memiliki kualitas yang lebih baik dari pada daging sapi, domba, dan kambing. Struktur seratnya lebih halus, warna dan bentuk menyerupai daging ayam. Daging kelinci mengandung protein tinggi serta kandungan lemaknya sedikit dan rendah kolestrol. Komposisi daging kelinci yaitu protein $20,8 \%$; lemak 10,2\%; air 67,9\%; kalori $7,3 \%$ $\mathrm{MJ} / \mathrm{kg}$ (Hasen, dkk. 2004).

Pada pemilihan ternak adalah dasar utama untuk menentukan produktivitas ternak adalah sifat reproduksi ternak. Pemilihan calon induk dan pejantan yang unggul merupakan strategi jitu agar target reproduksi ternak terpenuhi. Secara umum ternak kelinci unggul harus sehat yang ditandai mata cerah, telinga tidak terkulai, rambut di seluruh tubuh halus dan sehat, daerah mata, hidung, anus, mulut serta ekor bersih.

Bibit induk dan pejantan yang akan dipelihara mempunyai kriteria bobot badan yang sesuai dengan bangsa, umur dan jenis kelaminnya, dapat diketahui silsilah tetuanya yang mempunyai litter size tinggi, angka kematian anak rendah, berat lahir dan sapih yang tinggi (Acs et al., 2018; Fadli et al., 2019)

\section{MATERI DAN METODE}

Pelaksanaan penelitian mulai tanggal 8 Agustus sampai 21 Desember 2019 di peternakan Bapak Ahmad di Desa Nongko Sewu Tumpang Malang.

Ternak yang diamati sebanyak 54 ekor terdiri dari kelinci calon induk New Zealand White 14 ekor, Flamish Giant Lokal 20 ekor dan local 20 ekor. Peralatan penelitian terdiri dari alat ukur dalam satuan centimeter, timbangan, keranjang tempat kelinci dan alat recording untuk menulis dan dokumentasi gambar. Penelitian ini menggunakan metode studi kasus, sampel ditentukan dengan memilih kelinci calon induk yang berumur 9 bulan. Data morfometri yang diamati yaitu bobot badan dan ukuran tubuh (lingkar dada, dan panjang badan). Data dianalisis dengan korelasi dan regresi sederhana dengan software SPSS version 16.0.

Rumus korelasi tunggal:

$$
r=\frac{\sum x y}{\sqrt{\left(\sum x^{2}\right)\left(\sum y^{2}\right)}}
$$

Keterangan: $r=$ koefisien korelasi

Untuk menduga variasi fenotipe morfometri digunakan persamaan regresi berikut:

$$
a=\frac{\left[(\Sigma Y)\left(\Sigma X^{2}\right)-(\Sigma \mathrm{X})(\mathrm{XY})\right]}{\left(\mathrm{n} \Sigma \mathrm{X}^{2}\right)-(\Sigma \mathrm{X})^{2}}
$$




$$
b=\frac{[\mathrm{n}(\Sigma \mathrm{XY})-(\Sigma \mathrm{X})(\Sigma \mathrm{Y})]}{\left[\mathrm{n}\left(\Sigma \mathrm{X}^{2}\right)-(\Sigma \mathrm{X})^{2}\right]}
$$

Keterangan:

$\mathrm{b}=$ intercept

$\mathrm{Y}=$ Bobot badan

$\mathrm{X}=$ Panjang badan atau Lingkar Dada

$\mathrm{a}=$ konstanta

\section{PEMBAHASAN}

Data pengukuran dan penimbangan selama penelitian di peternakan rakyat dari calon induk kelinci NZW, FGL, dan L maka dapat diperoleh data pada Tabel 1.

Tabel 1. Nilai rataan morfometri dari calon induk kelinci NZW, FGL dan L

\begin{tabular}{cccc}
\hline \multirow{3}{*}{$\begin{array}{c}\text { Bangsa } \\
\text { kelinci }\end{array}$} & $\begin{array}{c}\text { Lingkar } \\
\text { Dada }(\mathrm{cm})\end{array}$ & $\begin{array}{c}\text { Rata-rata } \\
\text { Panjang } \\
\text { Badan } \\
(\mathrm{cm})\end{array}$ & $\begin{array}{c}\text { Bobot } \\
\text { Badan } \\
(\mathrm{kg})\end{array}$ \\
\hline NZW & $24,36 \pm 0,82$ & $27,32 \pm 0,91$ & $2,46 \pm 0,31$ \\
FGL & $22,98 \pm 0,79$ & $25,00 \pm 0,65$ & $2,40 \pm 0,15$ \\
L & $21,65 \pm 2,26$ & $22,15 \pm 1,48$ & $1,96 \pm 0,16$ \\
\hline
\end{tabular}

Berdasarkan hasil rataan fenotipe morfometri yang tertera dalam Tabel 1. Ukuran lingkar dada masing-masing NZW, FGL dan L adalah $24,36 \mathrm{~cm} ; 22,98 \mathrm{~cm}$ dan $21,65 \mathrm{~cm}$. Hasil penelitian ini lebih tinggi dari LD pada kelinci NZW umur 7 minggu 15,45 cm (Egena et al., 2014) dan lebih rendah daripada kelinci dewasa lokal yang dipelihara yang di Albania 29,1- 32,5 cm (Daija et al., 2010).

Ukuran panjang badan masing-masing $\mathrm{NZW}, \mathrm{FGL}$ dan $\mathrm{L}$ adalah $27,32 \mathrm{~cm} ; 25,00 \mathrm{~cm}$ dan $22,15 \mathrm{~cm}$. Hasil penelitian NZW dan FGL lebih tinggi serta kelinci $L$ lebih rendah daripada PB pada kelinci NZW umur 7 minggu $22,18 \mathrm{~cm}$ (Egena et al., 2014) dan lebih rendah daripada kelinci dewasa lokal yang dipelihara yang di Albania 41,60-50,50 cm (Daija et al., 2010).

Rataan bobot badan calon induk kelinci NZW, FGL dan $\mathrm{L}$ adalah $2,46 \pm 0,31 \mathrm{~kg}$, $2,40 \pm 0,15 \mathrm{~kg}$ dan $1,96 \pm 0,16 \mathrm{~kg}$. Bobot badan penelitian pada NZW, FGL dan L melebihi bobot badan pada kelinci NZW umur 7 minggu 424,9 gram atau 0,4249 $\mathrm{kg}$ (Egena et al., 2014) dan lebih rendah daripada kelinci dewasa lokal yang dipelihara yang di Albania 3,4-4,7 kg (Daija et al., 2010).

Perbedaan berbagai fenotipe morfometri hasil penelitian berbeda dengan 41enetic41re karena pengaruh lingkungan yang berbeda, Lingkungan tersebut diantaranya adalah pakan, dan manajemen pemeliharaan. Sebagaimana pendapat dari Mudawamah (2017) bahwa fenotipe seekor ternak merupakan hasi pengaruh genetik dan lingkungan serta interaksi antara genetik dan lingkunga. Lingkungan ternak yang mempengaruhi adalah jenis dan jumlah pakan yang diberikan dan tatalaksana pemeliharaan.

Beberapa hasil penelitian ditampilkan dalam bentuk tabel yaitu variasi fenotipe (Tabel 2), hubungan korelasi (Tabel 3) dan persamaan regresi (Tabel 4) berbagai bangsa kelinci.

Tabel 2. Variasi fenotipe calon induk kelinci NZW, FGL dan L

\begin{tabular}{cccc}
\hline $\begin{array}{c}\text { Bangsa } \\
\text { Kelinci }\end{array}$ & $\begin{array}{c}\text { Lingkar } \\
\text { Dada }\end{array}$ & $\begin{array}{c}\text { Panjang } \\
\text { Badan }\end{array}$ & $\begin{array}{c}\text { Bobot } \\
\text { Badan }\end{array}$ \\
\hline NZW & 0,67 & 0,83 & 0,10 \\
FGL & 0,62 & 0,42 & 0,02 \\
L & 5,11 & 2,19 & 0,03 \\
\hline
\end{tabular}

Tabel 3. Nilai korelasi dan koefisien determinasi fenotipe morfometri pada calon induk kelinci NZW, FGL dan L

\begin{tabular}{|c|c|c|c|c|}
\hline \multirow[t]{2}{*}{$\begin{array}{l}\text { Bangsa } \\
\text { Kelinci }\end{array}$} & \multicolumn{2}{|c|}{$\begin{array}{c}\text { Hubungan } \\
\text { Bobot Badan } \\
\text { dan Panjang } \\
\text { Badan }\end{array}$} & \multicolumn{2}{|c|}{$\begin{array}{l}\text { Hubungan } \\
\text { Bobot } \\
\text { Badan dan } \\
\text { Lingkar } \\
\text { Dada }\end{array}$} \\
\hline & $r$ & $r^{2}$ & $r$ & $r^{2}$ \\
\hline NZW & ,053 & ,231 & 105 & ,324 \\
\hline FGL & 158, & 398 & ,007, & 089, \\
\hline $\mathrm{L}$ & 198, & 445, & ,038, & 196 \\
\hline
\end{tabular}

Tabel 4. Persamaan regresi hubungan BB terhadap PB dan LD

\begin{tabular}{|c|c|c|}
\hline \multirow{2}{*}{$\begin{array}{l}\text { Bangsa } \\
\text { Kelinci }\end{array}$} & \multicolumn{2}{|c|}{ Rata-rata } \\
\hline & $\begin{array}{l}\text { Hubungan } \\
\text { BB dan PB }\end{array}$ & $\begin{array}{l}\text { Hubungan } \\
\text { BB dan LD }\end{array}$ \\
\hline NZW & $\mathrm{BB}=4,579-\mathbf{0 , 0 7 8 \mathrm { PB } ^ { \mathrm { mi } }}$ & $\overline{B B}=-0,490+0,121 L D^{\mathrm{tm}}$ \\
\hline FGL & $B B=4,631-0,089 P^{B n}$ & $\mathrm{BB}=2,762-0,016 \mathrm{LD} \mathrm{D}^{\mathrm{tn}}$ \\
\hline $\mathrm{L}$ & $B B=0,906+0,048 P B^{*}$ & $B B=1,664+0,014 L D^{t n}$ \\
\hline
\end{tabular}

Berdasarkan hasil variasi fenotipe morfometri yang tertera dalam Tabel 2. Variasi fenotipe lingkar dada masing-masing NZW, FGL dan $L$ adalah 0,$67 ; 0,62$ dan 5,11. Hasil penelitian ini variasi fenotipe LD pada kelinci NZW, FGL dan $L$ lebih tinggi dibandingkan dengan variasi fenotipe NZW umur 7 minggu 0,03 (Egena et al., 2014). Variasi fenotipe LD pada kelinci NZW dan FGL lebih rendah dan L lebih tinggi dibandingkan variasi minimal pada kelinci dewasa Albania $(0,90)$, tetapi kelinci L mempunyai variasi fenotipe LD lebih rendah dibandingkan variasi fenotipe dan lebih rendah daripada kelinci dewasa lokal yang dipelihara yang di Albania yaitu 12,82 (Daija et al., 2010). 
Berdasarkan hasil variasi fenotipe morfometri yang tertera dalam Tabel 2. Variasi fenotipe PB masing-masing NZW, FGL dan L adalah 0,$83 ; 0,42$ dan 2,19. Hasil penelitian ini variasi fenotipe PB pada kelinci NZW, FGL dan $L$ lebih rendah dibandingkan dengan variasi fenotipe NZW umur 7 minggu 17,98 (Egena et al., 2014). Variasi fenotipe PB pada kelinci $L$ lebih tinggi dibandingkan variasi minimal pada kelinci dewasa Albania $(1,464)$ dan kelinci $L$ mempunyai variasi fenotipe LD lebih rendah dibandingkan variasi fenotipe maksimal kelinci dewasa lokal yang dipelihara yang di Albania yaitu 6,20 (Daija et al., 2010).

Variasi fenotipe BB masing-masing NZW, $F G L$ dan $L$ adalah 0,$10 ; 0,02$ dan 0,03 . Hasil penelitian ini variasi fenotipe $\mathrm{BB}$ pada calon induk kelinci NZW, FGL dan L lebih rendah dibandingkan dengan variasi fenotipe NZW umur 7 minggu 17,98 (Egena et al., 2014). Variasi fenotipe PB pada kelinci NZW lebih tinggi sedangkan $F G L$ dan $L$ lebih rendah dibandingkan variasi minimal dan maksimal pada kelinci dewasa Albania yaitu 0,03-0,30 (Daija et al., 2010).

Variasi fenotipe morfometri kelinci jenis NZW pada (Tabel. 2) cukup tinggi dengan nilai lingkar dada dan panjang badan yang tinggi, hal ini disebabkan oleh faktor genetik yang dimiliki kelinci NZW lebih baik dibandingkan dengan ke dua jenis kelinci lainya ( $F G L$ dan $L$ ), hal ini di dukung dengan pernyatan Fafarita (2006) ukuran tubuh sangat dipengaruhi oleh genetik suatu ternak. Pencampuran gen yang terjadi dalam satu rumpun ternak terjadi karena adanya persilangan antar bangsa kelinci yang dapat menyebabkan perubahan genetik suatu jenis kelinci (Ibrahim et al., 2007; Carneiro et al., 2011; Ragab et al., 2016) perbedaan ukuran tubuh dalam suatu populasi juga bisa disebabkan karena adanya percampuran gen bangsa kelinci lain yang terdapat dalam kelinci tersebut akibat adanya perkawinan silang antar bangsa kelinci tersebut. Sesuai dengan pendapat Fadli et al. (2018) bahwa NZW bergenotipe $A B, F G L$ bergenotipe $A B$ dan $L$ bergenotipe $B B$ dilihat dari gen pertumbuhan berdasarkan analisis PCR-RFLP.

Dari hasil perhitungan korelasi dan koefisian determinan fenotipe pada berbagai calon indukan kelinci NZW, FGL dan L didapatkan hasil yang tertera pada Tabel. 3 bahwa hubungan fenotipe morfometri bersifat positif, sesuai dengan pendapat Rohimah dkk (2017) bahwa terdapat hubungan yang positip antara berbagai karakter kuantitatif pada pejantan kelinci. Keeratan hubungan fenotipe morfometri hasil penelitian sangat rendah sampai rendah karena nilai $r$ masuk dalam rentan nilai $<0,20$ yang berarti sangat rendah sampai rendah keeratannya. Menurut Burhanuddin (2012) nilai $r$ yaitu 0,25-0,5 termasuk keeratan sedang. Nilai koefisien determinasi $L$ hubungan antara bobot badan dan panjang badan sebesar 0,198 artinya bahwa bobot badan calon induk kelinci L 19,8\% dipengaruhi oleh panjang badan dan faktor lainnya $(91,2 \%)$ yaitu genetik dan pakan .

Korelasi dan koefisian determinan fenotipe pada berbagai calon indukan kelinci NZW, FGL dan $L$ lebih rendah dari hasil penelitian Akinsola et al. (2014) pada kelinci dewasa yang menyatakan nilai $r$ pada berbagai sifat morfometri $>0,60$. Perbedaan ini disebabkan umur dan genetik serta lingkungan yang berbeda.

Persamaan regresi yang berbeda nyata hanya ditemukan pada $L$ hubungan antara bobot badan dan panjang badan dengan persamaan regresi $\mathrm{BB}=0,906+0,048 \mathrm{~PB}$ artinya bahwa setiap peningkatan $1 \mathrm{~cm}$ PB akan diikuti oleh kenaikan BB sebesar 0,048 gram.

\section{KESIMPULAN}

Variasi fenotipe ukuran tubuh calon induk kelinci Lokal paling tinggi dibandingkan dengan calon induk kelinci New Zealand White dan Flamish Giant Lokal, sedangkan variasi fenotipe bobot badan paling tinggi pada calon induk New Zealand White. Nilai korelasi dan determinasi hubungan sifat morfometri pada calon induk New Zealand White, Flamish Giant Lokal dan Lokal kategori sangat rendah sampai rendah keeratannya. Terdapat hubungan antara bobot badan dan panjang badan pada induk kelinci $\mathrm{L}$ dengan persamaan regresi $\mathrm{BB}=0,906+0,048$ PB.

\section{Saran}

Jika ingin memilih calon bibit induk kelinci berdasarkan panjang badan dan lingkar dada yang seragam hendaknya dipilih New Zealand White sebaliknya jika ingin memilih bibit induk berdasarkan panjang badan dan lingkar dada untuk meningkatkan variasi dalam populasi maka dipilih bibit induk kelinci lokal. Jika ingin memilih calon bibit induk kelinci berdasarkan bobot badan yang seragam hendaknya dipilih Flamish Giant Lokal sebaliknya jika ingin memilih bibit induk berdasarkan bobot badan untuk meningkatkan variasi dalam populasi maka dipilih bibit induk kelinci New Zealand White. Perlu dilakukan lebih lanjut variasi fenotipe, regresi dan korelasi morfometri pada anak kelinci betina atau induk kelinci. 


\section{DAFTAR PUSTAKA}

Acs, V., K. Szendo, H. Garreau, T. Donko, Z. Matics, and I. Nagy. 2018. Application possibilities of selection indices in Pannon White rabbits breeding program. Italia journal of Animal Scince. 17(4): 884-889.

Akinsola, O. M., B. I. Nwagu, M. Orunmuyi1, G. T. lyeghe-Erakpotobor, E. D. Eze, O. T. F. Abanikannda, O. Onaadepo, E.U. Okuda and U. Louis. Prediction of bodyweight from body measurements in rabbits using principal component analysis. Annals of Biological Sciences. 2014, 2 (1):1-6

Burhanuddin, M. 2012. Koefisien korelasi, Signifikansi dan Determinasi. https://alvin burhani.wordpress.com/2012/06/28/koefisie n-korelasi-signifikansi-determinasi/

Carneiro, M., S. Afonso, A. Geraldes, H. Garreau, G. Bolet, S. Boucher, A.

Tircazes, G. Queney, M.W. Nachman, and N. Ferrand. The Genetic Structure of Domestic Rabbit. Molecular Biology and Evolution. 28(6):1801-1816.

Daija, A., L. Papa, and K. Kume. 2010. Local Differentiation of Albanian Rabbit Populations. Journal of Tekirdag Agricultural Faculty. Vol. 2: 187-190.

Egena, S. S.A, Akpa, G. N, Aremu, A. And Alemede, I. C. 2014. Sources of Shared Variability In Body Weight And Linear Body Measurement Traits of Two Breeds of Rabbit. International Journal of Plant, Animal And Environmental Sciences. Vol 4: 141-145.

Fadli, M. Z., M. Mudawamah, and O. R. Puspitarini. 2019. Productivity of Angora rabbits under exogenous PMSG and HCG. 4(6):343-348.

Fadli, M. Z., M. Mudawamah, O. R. Puspitarini and G. Ciptadi. 2018. Superiority Of Filial Rabbits Derived From Purebred And Indonesian Localbred Based On Phenotype And Genotype. International Journal of Agriculture, Environment and Bioresearch. Vol. 3: 406-612. http://ijaeb.org/uploads2018/AEB 03 286.p df

Fafarita, L., 2006. Karakteristik Sifat Kualitatif Dan Kuantitatif Kelinci Flemish Giant, English Spot, dan Rex di Kabupaten Magelang, Program Studi Teknologi produksi Ternak,
Fakultas Peternakan, Institut Pertanian Bogor.

Hassen, A., D. E. Wilson. R. Rouse dan G. R. Tait Jr. 2004. Use of Linear and Non-Linear Growth Curves to Describe body weigt Changes of Young Angus Bull and Haifers. Lowa State University Animal Industri Report

Ibrahim, M.K., M.M. Iraqi, S.H. Hasan, A.S. ElDeghadi. 2007. Crossbreeding genetic effects for growth and liveability traits in rabbit raised under hot climate conditions.

Ragab, M. J.P. Sanchez, C. Minguez, M. Baselga. 2016. Crossbreeding Effects On Rabbit Reproduction From Four Maternal Lines Of Rabbits. Animal. 10(7):10861092.

Rohimah, Mudawamah, dan S. Susilowati. 2017. Hubungan Karakter Kuantitatif Ukuran Tubuh pada Berbagai Bangsa Pejantan Kelinci. 2(2):1-5.

Sartika, T., 2005. Komoditi kelinci peluang agribisnis peternakan. Seminar Nasional Agribisnis Peternakan dan Perikanan pada Pelita VI. Media. Edisi Khusus: 397-398.

Simonova, M.P. L. Chrastinova, J. Mojto, A. Laukova, R. Szaboova, and J. Rafay. 2010. Quality of Rabbit Meat and Phyto-Additives. Czech J. Food Sci. Vol. 28, 2010, No. 3: 161-167

Wang, J., S. Yuan, M.A. Elzo, X. Jia, S. Chen, and S. Lai. Comparison Of Carcass And Meat Quality Traits Among Three Rabbit Breeds. Korean J. Food Sci. Anim. Resour. 36 (1):84-89.

Zotte, A.D. 2002. Perception of rabbit meat and major factors influencing the rabbit carcass and meat quality. Livestock Production Science 75(1):11-32 